\title{
Variation and Change
}

The Dynamics of Maltese in Space, Time and Society

Sandro Caruana, Ray Fabri, Thomas Stolz (Eds.)

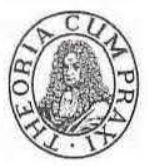

Akademie Verlag

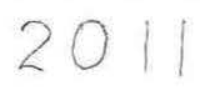




\title{
JOSEPH M. BRINCAT (MALTA) \\ Describing literary Maltese: concordances to Dun Karm and Rużar Briffa
}

\begin{abstract}
In 2007 Oliver Friggieri published in one volume all the poems written by Dun Karm Psaila, which were previously scattered in various newspapers and rare periodicals. This provided a long-awaited opportunity to study the local variety of Italian belonging to the literary genre and I decided to start with a concordance to Dun Karm's poems. I then thought it worthwhile to compare his lexicon with that of his Maltese poems. Another step was a comparison between Dun Karm's lexical choices and those of another highly-rated Maltese poet, Rużar Briffa. In this paper I present and compare the results obtained by three students, Catherine Aquilina, Olivia De Brincat and Christian Sciberras who wrote dissertations under my guidance.
\end{abstract}

\section{Taqsira}

L-edizzjoni tal-poeżiji li Dun Karm Psaila kiteb bit-Taljan offriet, fl-2007, opportunità wisq mistennija biex jigi studjat it-Taljan ta' Malta fil-varjetà letterarja tieghu u bdejt bi progiett biex jinbnew ilkonkordanzi, lista tal-kliem kollu użat f'dawn il-poeżiji. Ġietni wkoll il-kurżità biex inqabbel il-kliem użat mill-istess awtur fil-poeżija bit-Taljan mal-kliem użat fil-poeżija bil-Malti. Deherli utli wkoll inqabbel it-tendenzi fl-ghażla tal-vokabolarju bejn Dun Karm u Rużar Briffa. Bix-xoghol ta' tliet studenti, Catherine Aquilina, Olivia De Brincat, u Christian Sciberras, inkisbu dawn ir-riżultati.

\section{Introduction}

The status of the Maltese language reached new heights in 2003 when it was recognized as one of the official languages of the European Union. Of course, this would not have been possible had it not achieved official status in Malta itself in 1934. A lot has been written about the efforts of scholars and politicians who fought out the intense battle known as the Language Question between the last two decades of the nineteenth century and the first three decades of the twentieth, but most of the contributions represented the political and patriotic viewpoints. Gramsci wrote:

Every time the question of the language surfaces, in one way or another, it means that a series of other problems are coming to the fore: the formation and enlargement of the governing class, the need to establish more intimate and secure relationships between the governing groups and the national-popular mass, in 
other words to reorganize the cultural hegemony (Romaine 1998: 51; the original

is in Gramsci 1975: 2346).

These words could have been written with the Maltese Language Question in mind, and show how important it is, now that the dust has settled, to sift the essentially linguistic aspects from the politically charged controversy (see Hull 1993 and Brincat 2001). This does not mean that the emblematic significance of language has in any way diminished; however, it must not overshadow the lengthy, multi-faceted process of standardization. The action of politicians, although decisive, would not have been possible without the previous, steady build-up undertaken by scholars, poets and novelists much before the flare-up of the Language Question (Brincat 2000: 125-153; 2010: chapters 7, 8).

\section{The standardization of the Maltese language}

In Malta the process of standardization actually started in the eighteenth century. At first it was limited to the scholarly, "antiquarian" field, an approach that documented and attempted the reconstruction of ancient languages, until Michel Anton Vassalli applied the Enlightenment's principle of education for the people in their own tongue. According to Garvin \& Mathiot (1956), standardization is created by codification, intellectualization, a unifying function, a distinguishing function, prestige and a frame-ofreference function. Other scholars deduct or add other criteria or functions (Ammon 1986), but most linguists agree that the standardization of a language depends on the convergence of various factors. Without any doubt, the national languages of Europe were standardized through literary works, grammatical description, use in administration, law and religion, and their teaching in the schools. All these factors and functions together raised one of the dialects of a country to official status. Unfortunately, nonspecialists still believe that dialects are corrupt forms of "the" language, but this notion was disproved around 1860. Standard languages arose mainly in the capital cities, simply because that was the place where the above-mentioned criteria converged.

In Malta, as elsewhere, the first steps in standardization were taken by writers and grammarians. After sporadic attempts by other scholars, Ignazio Saverio Mifsud and Francesco Agius De Soldanis produced the first religious and theatrical writings with literary flair, and the same De Soldanis, Padre Pelagio and Vassalli compiled dictionaries and grammars (Cassar Pullicino 2001). In the nineteenth century the Romantic influence of Italian writers who found refuge in Malta inspired nationalistic poems and novels and, with admirable foresight, Francesco Vella produced grammars and readers for the schools (which were then few and badly organized) and Gian Anton Vassallo wrote poems and history books with the average reader in mind. These pioneers' example was followed throughout the nineteenth century, and so Maltese literature grew steadily in quantity and quality (Friggieri 1979), despite British scepticism as represented by Badger in 1841 . Literary production in Maltese was a conscious effort to confer prestige on the standar- 
dized harbour/city variety and raise it above the rural varieties (dialects) to the status of a language. This was the safest and surest way to counteract the Anglicization of Malta which, according to Victorian principles, the government believed was essential for the island's progress. These efforts had become indispensable because the British were set on replacing Italian by English, especially when Italy became a unified nation in 1861-70, and even more so when the Fascists took power in the 1920s (Brincat 2000: 142-153, 171-176; 2010: chapters 8,9) . Comparison with what happened in Ireland, where Gaelic had no literary prestige, suggests that a similar fate would have befallen Maltese (achieved by the same Patrick Keenan, who is said to have vowed to "make a perfect English gentleman out of every Irish boy"), were it not for the defence of the local use of Italian language and literature which acted as a cultural shield that gave Maltese time to develop a literature of its own.

Nowadays, standardization is more dependent on the media than on literature (Ammon 2004), and one must not underestimate the role of the Rediffusion set which brought Standard Maltese into every home in Malta and Gozo from 1935 onwards, thus establishing a norm of reference to all dialect-speakers, a decade before compulsory elementary education was introduced in 1946. In those days the prestige of the language relied on its literature, and although one may wonder how many people were actually familiar with Dun Karm's poems (feuilletons reached a much wider audience), the high quality of Dun Karm's verse did earn respect for Maltese, even among its former detractors between 1912 and 1934.

On the more practical level, the codification of Maltese was mainly based on its literature, which was considered the highest expression of the language, and therefore provided a homogeneous model for written Maltese. This approach in teaching continued up to the 1960s, perhaps even till the 1970s, when a more functional approach was introduced. Considering that artistic expression inherently distances itself from the practical plane, today one may ask whether, or up to what extent, classical Maltese poetry is still communicative to the average Maltese reader or listener. Oliver Friggieri (1976) has shown that Dun Karm's style was heavily influenced by Leopardi, Carducci and D'Annunzio, the authors he studied, loved and taught. One of the main characteristics of their style was the quest for the "parola peregrina" (the beautiful word) by retrieving obsolete words or coining new ones from old roots. The puristic trend, so typical of the early Romantics, dominated Maltese writers for two reasons: they all wrote Italian, and so they automatically shunned the use of Italian words because they considered Maltese as a different medium; and they conceived their art as a mission for recovering a lost language and assert its autonomy. This was in line with the belief that ancient languages were more noble than modern ones and therefore conferred prestige on their speakers.

Poetry was generally considered as the pinnacle of linguistic expression. Matthew Arnold defined poetry as "nothing less than the most perfect speech of man" and the schema devised by Gaetano Berruto (1987) to illustrate Coseriu's description of varieties places the literary variety at the top left hand corner, at the higher end of the three axes of formal- 
ity, upper social level and written register. Oliver Friggieri describes Dun Karm's choice of vocabulary in his Italian poems as "markedly classical", and states that the poet introduced similar choices in his Maltese poems, achieving the high-flown style by creating neologisms from existing roots. Friggieri adds that Dun Karm slowly abandoned the very formal register and adopted a vocabulary that was closer to contemporary speech.

\section{The need for a concordance of the major Maltese poets}

Literary critics substantiate their statements by citing a few significant examples, but linguists need to be more precise, which is why this paper shall henceforth produce tables full of numbers. The only way to do this is by analyzing the concordance to literary works. The first concordance to the Bible was produced as early as 1736 , followed by concordances to Shakespeare and other classical writers in the eighteenth century. During the twentieth century electronic methods made it easier to draw up concordances and some became available on the web, like the University of Dundee's Web Concordances to the English Romantic poets. The aims and uses of concordances are many: first of all they provide a quick reference to the text; they give the exact size of an author's vocabulary and allow the analysis of his particular choices. They make it easy to calculate the relative percentages of native and foreign words, the number and character of coinages, the vocabulary's relation to the author's regional dialect. They also help to draw a picture of the stage reached by the language in a given period.

When Oliver Friggieri published the collection of Dun Karm's Italian poems in 2007, I realized that its concordance would be extremely useful to a description of the variety of Italian used in Malta. I therefore assigned the task of drawing it up to a diligent and reliable student reading for an Italian Honours degree, Olivia De Brincat (2009), who had asked me to be her tutor for the B.A. Hons. dissertation. Comparison of her results with a concordance of Dun Karm's Maltese poems was the next step, and the daunting venture was boldly undertaken by another Honours student, Christian Sciberras (2009). The year before, I had asked Catherine Aquilina (2008), who had proposed a study of Rużar Briffa's poetic vocabulary, to draw up a concordance too, and this allowed us to compare the choice of words of two major Maltese poets and thus find out more about different attitudes to the adoption of Italian words in Maltese poetry.

The criteria I set were that two lists would be drawn up, one with headwords in alphabetical order and one with headwords in a descending order of frequency. Each headword would carry a tag describing its grammatical category. In this way a distinction was made between function words (pronouns, conjunctions, invariable participles, the article, prepositions and interjections) and content words (nouns, adjectives, verbs and adverbs). Besides this, usage tags were added, modelled on Tullio De Mauro's Grande Dizionario Italiano dell'Uso (2000), known as GDU or GRADIT, which contains 250,000 entries. De Mauro identifies as FO (fondamentale) the core vocabulary of 
about 2,000 words which constitute $92 \%$ of any text (e.g. cat, dog, chicken). The tag $\mathrm{AU}$ (alto uso) marks the next 2,500 highly used words which form $6 \%$ of any text (e.g. goat) while $\mathrm{AD}$ (alta disponibilità) indicates about 2,000 words which are well-known but not often used (e.g. shark). According to De Mauro's calculations, these 6,500 words form between 97 and 99 per cent of any text. Other tags are CO (comune) describing about 50,000 commonly used words, BU (basso uso, low use), RAR (rare), OB (obsolete), FOR (of foreign origin), TS (technical/specialized terms), LE (literary terms), TOP (place-names), COGN (surnames), STOR (historical terms), RE (regional words), ETN (ethnic terms). The application of these tags was done as perceived by the students themselves (what terms they felt as common, rare or obsolete) but they consulted Mifsud \& Borg's Threshold Level list (1997) to define the fundamental terms.

\section{A concordance to the poems of Dun Karm and Rużar Briffa}

Christian Sciberras discovered that in Dun Karm. Il-poeziji mig̈bura, edited by O. Friggieri (1980), the poet used 65,569 words, of which 3,190 are different lexemes. Their etymological analysis of the total number of words used shows 63,083 words of Arabic origin $(96.2 \%)$ and 2,204 words of Italian or Sicilian origin (03.4\%). However, the 3,190 different lexemes (headwords) show a different ratio: 2,587 lexemes are of Arabic origin $(81.1 \%)$ and 464 lexemes are of Italian or Sicilian origin (14.5\%). The use of other languages is very limited: there are 19 different Latin lexemes, 34 English words, 7 French, 3 German and 1 Spanish word. The count of usage tags shows 1,153 common words (adding up $\mathrm{FO}, \mathrm{AU}$ and $\mathrm{AD}), 1,333$ words that are not used often in ordinary language (BU), 189 rare, 110 obsolete and 40 technical and specialized terms. We decided to designate as CO De Mauro's three categories, fundamental, highly-used and well-known but not frequently-used (FO, $\mathrm{AU}$ and $\mathrm{AD}$ ), grouped together, because it was not easy to distinguish between them. A few typical examples taken from the list are shown in the Appendix.

The comparison between the concordances of the three texts that were analyzed is presented in the following tables, showing the number of occurrences in descending order (1-20 in rank) for High-frequency words divided into nouns (Table 1), adjectives (Table 2) and verbs (Table 3):

\begin{tabular}{|c|c|c|c|c|c|}
\hline \multicolumn{2}{|c|}{ Dun Karm, Italian } & \multicolumn{2}{|c|}{ Dun Karm, Maltese } & \multicolumn{2}{|c|}{ Rużar Briffa, Maltese } \\
\hline cielo & 131 & ilma & 584 & qalb & 160 \\
\hline sole & 131 & qalb & 557 & $\hbar a j j a$ & 80 \\
\hline amore & 130 & sema & 305 & qedem & 62 \\
\hline cuore/corelcor & 114 & $\hbar s i e b$ & 238 & triq & 61 \\
\hline Dio & 105 & $m \hbar a b b a$ & 237 & dar & 60 \\
\hline mondo & 89 & $\hbar a j j a$ & 232 & $m \hbar a b b a$ & 59 \\
\hline mare & 62 & Alla & 229 & ghanja & 56 \\
\hline fiore & 61 & warda & 194 & warda & 54 \\
\hline vita & 61 & xemx & 186 & art & 52 \\
\hline
\end{tabular}




\begin{tabular}{|c|c|c|c|c|c|}
\hline \multicolumn{2}{|c|}{ Dun Karm, Italian } & \multicolumn{2}{|c|}{ Dun Karm, Maltese } & \multicolumn{2}{|c|}{ Rużar Briffa, Maltese } \\
\hline mano & 60 & dar & 184 & Allalalla & 50 \\
\hline luce & 59 & formm & 184 & $d a w l$ & 47 \\
\hline signore & 54 & gћajn & 180 & ferh & 42 \\
\hline terra & 53 & żmien & 179 & żmien & 42 \\
\hline occhio & 52 & kelma & 171 & xemx & 41 \\
\hline giorno & 50 & art & 165 & dinja & 40 \\
\hline pace & 49 & dawl & 152 & rih & 40 \\
\hline petto & 49 & omm & 140 & demm & 39 \\
\hline seno & 49 & hena & 139 & gћajn & 36 \\
\hline uomo & 47 & ghanja & 132 & $\hbar$ sieb & 36 \\
\hline gioia/gloria & 46 & bahar & 130 & lejl & 36 \\
\hline
\end{tabular}

Table 1: High-frequency words: nouns

The lexemes in this table show that the main topics treated by Dun Karm and Rużar Briffa are religion, nature and feeling, consequently the words used most frequently belong to the core lexicon. No less than ten terms out of 20 are found in all three columns: sole/xemx/xemx, amore/mhabba/mhabba, cuore/core/cor/qalb/qalb, Dio/Alla/ Alla/alla, fiore/warda/warda, vita/hajja/hajja, luce/dawl/dawl, terra/art/art, occhio/ ghajn/ghajn, gioia/hena/ferh. Moreover, two more concepts are used in both languages by Dun Karm, namely cielo/sema, mare/bahar, bringing the total of corresponding terms to 12 out of 20 . The accent on affection is shown in the Italian poems of Dun Karm by the words petto and seno, apart from amore and cuore/core/cor.

Four more lexemes are common to both Dun Karm and Briffa: $\hbar s i e b$, dar, żmien and ghanja ('thought, home or house, time' and 'song'). The words that stand out are ilma ('water'), ranked number 1 in Dun Karm, and qalb ('heart') which is number 2 in Dun Karm and number 1 in Briffa, where its occurrence is double that of the next word, hajja ('life').

\begin{tabular}{|c|c|c|c|c|c|}
\hline \multicolumn{2}{|c|}{ Dun Karm, Italian } & \multicolumn{2}{|c|}{ Dun Karm, Maltese } & \multicolumn{2}{|c|}{ Rużar Briffa } \\
\hline grande & 92 & sabih & 177 & kbir & 54 \\
\hline bello & 71 & helu & 157 & ghajjien & 47 \\
\hline eterno* & 63 & kbir & 157 & sabih & 45 \\
\hline divino* & 58 & ckejken & 109 & ftit & 32 \\
\hline alto & 46 & hanin & 98 & mistrieh & 32 \\
\hline dolce & 43 & safi & 92 & fqir & 24 \\
\hline bianco & 38 & qawwi & 81 & wisq & 22 \\
\hline santo* & 33 & tajjeb & 65 & hiemed & 21 \\
\hline lieto & 31 & mohbi & 57 & bosta & 18 \\
\hline sereno & 28 & $a \hbar \hbar a r$ & 53 & Malti & 18 \\
\hline gentile & 27 & hieni & 50 & $\dot{z} a g \hbar z ̇ u g \hbar$ & 17 \\
\hline novello & 27 & shih & 48 & shih & 16 \\
\hline caro & 26 & $a \hbar \operatorname{rax}$ & 45 & mbieghed & 16 \\
\hline solo & 25 & $\dot{g} d i d$ & 45 & ghani & 15 \\
\hline sacro* & 23 & hafif & 44 & ghażiż & 15 \\
\hline soave & 23 & qalbieni & 39 & hieni & 15 \\
\hline lento & 22 & mqaddes* & 36 & mdejjaq & 15 \\
\hline nero & 22 & sieket & 36 & minsi & 15 \\
\hline
\end{tabular}




\begin{tabular}{|c|c|c|c|}
\hline Dun Karm, Italian & Dun Karm, Maltese & Rużar Briffa & \\
\hline pio* $^{*}$ & iswed & $\dot{z} g \hbar \dot{ } i r$ & 15 \\
\hline superbo & $m a \hbar b u b$ & ferhan/gdid & 14 \\
\hline (* religious terms) & miskin & iswed/mitluf/xih & 14 \\
\hline
\end{tabular}

Table 2: High-frequency words: adjectives

Identical adjectives common to all three columns are only five, but significantly the two most frequently used words occupy the first two places in the Italian poems of Dun Karm and two of the three top places in Dun Karm's and Rużar Briffa's Maltese poems: grande/kbir/kbir, and bello/sabih/sabih. The others are lieto/hieni/hieni, novello/gdid/ $\dot{g} d i d$, and nero/iswed/iswed. Only one term is common to Dun Karm and Briffa's Maltese poems, shih. The predominantly religious character of Dun Karm's Italian poems is shown by eterno, divino, santo, sacro, and pio, while their positive character is shown by the adjectives grande, bello, alto, dolce, bianco, lieto, sereno, gentile, caro, soave, to which one may add superbo. In his Maltese poems the religious aspect is less evident

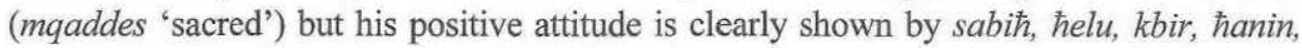

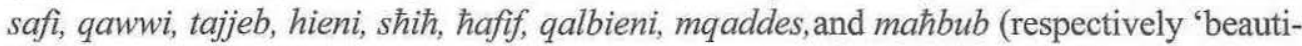
ful, sweet, great, kind, pure, strong, good, happy, whole, light/fast, bold, sacred', and 'loved'). On the contrary, the negative outlook of Briffa is shown by ghajjien, fqir,

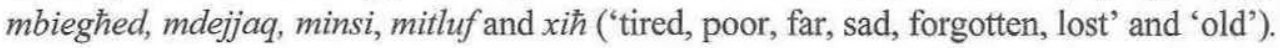

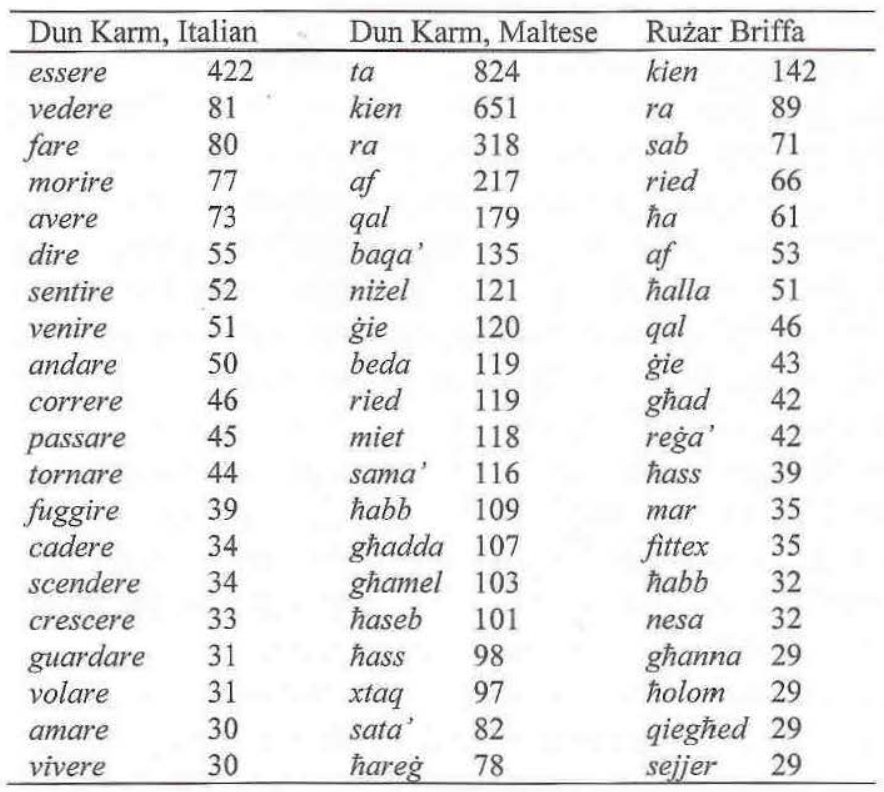

Table 3: High-frequency words: verbs

In Dun Karm's Italian poems, apart from the obvious verbs that concern the senses vedere and guardare ('to see', 'to look') and sentire ('to hear' and 'to feel'), the fundamental 
fare, avere, dire, amare ('to do, to have, to say, to love'), and the intransitives essere, morire, crescere, vivere ('to be, to die, to grow, to live'), one notes an abundance of verbs of motion: venire, andare, correre, passare, tornare, fuggire, cadere, scendere, volare ('to come, to go, to run, to pass, to return, to escape/avoid, to fall, to fly'). On the contrary, in his Maltese poems Dun Karm has only four verbs of motion in the top twenty (niżel, gie, ghadda, ћareg 'to go down, to come, to pass, to go out'). On the other hand, Rużar Briffa has only three verbs of motion (gie, mar, sejjer, 'to come, to go, to be about to go') of which, one must point out that gie and sejjer frequently have an auxiliary function. Six verbs are found in all three columns, and another two in the Maltese poems of both Dun Karm and Briffa, but they all belong to the core vocabulary.

\section{The literary lexicon}

In the above tables we have analyzed only the 20 most frequent words in each of three categories - nouns, adjectives and verbs, for a total of 60 words taken from each collection of poems but, as we have seen, the exercise produced some interesting results. Valuable considerations arise also from the analysis of the total vocabulary of each collection. Dun Karm wrote 146 poems in Italian and 334 poems in Maltese, using 4,785 and 3,189 different lexemes respectively. It is rather odd to observe that Dun Karm's Italian vocabulary is richer than that used in Maltese, the difference being 1,596 lexemes more although the Italian poems are 188 less. This may be due to the fact that in Maltese Dun Karm tended to treat the same topics, but this impression needs verification. The trend could also be due to his effort at Semitization, since the core Maltese vocabulary contains basic words, many of which are hypernyms (umbrella terms) that, in literature, especially in poetry, can replace the more precise terms. Rużar Briffa, too, kept a very low lexical count: in 201 poems he used only 1,890 different lexemes, less than half the words used by Dun Karm in his 146 Italian poems. However, the ratio between function words and content words does not differ much in Dun Karm's Italian and Maltese poems - 41.6\% and $38.2 \%$ function words and 58.4 and $61.4 \%$ content words respectively. Headwords of Semitic origin in Dun Karm are 2,587 (81.1\%) and in Briffa 1,545 (81.7\%). Headwords of Sicilian and Italian origin in Dun Karm are 464 and in Briffa 308, which work out at $14.55 \%$ and $16.3 \%$ respectively. Their occurrences, too, are slightly higher in Briffa than in Dun Karm, $4.1 \%$ against 3.36\%, and they are almost all content words.

It is important to note that in the Maltese poetry of both authors the lexicon is very basic because Dun Karm uses just over 3,000 words and Rużar Briffa just under 2,000 different headwords. This figure is comparable to De Mauro's 2,000 fundamental words (FO) and one half of the highly-used words (AU). One may keep in mind that the vocabulary in the Maltese edition of the Threshold Level consists of 1,585 different words, of which 748 are of Arabic origin (46\%), 641 are of Sicilian and Italian origin (40\%) and 196 are English words (12\%). The comparison gives an idea of how different the register 
of classical poetry is from today's informal variety of Standard Maltese. Threshold words that correspond to Dun Karm's poetic lexicon are only 601 out of 1,585.

A couple of excerpts from Dun Karm's poems may help to evaluate the distance between the poetic register and everyday speech.

\section{Il-Jien u lil hinn Minnu}

\section{Lill-Pjacir}

(1938)
Harist madwari; rajt il-ward ilellex bl-eluf u jilghab mal-fewgiet ghaddejja; smajt lill-aghsafar mohbijin fix-xuxa tal-fraxxnu u tal-harrub ighannu l-ghanja ferrieћa ta' l-imћabba u x-xemx mill-gholi tiddi fuq kollox u bis-shana wtieqa tfittex l-eghruq tal-hajja. Dehra helwa!
Qarrieq mill-bidu, rsaqt bil-kelma rżina fuq l-ewwel mara u bdejt il-hajr ghad-dnub; hi, fiergha, m'gharfitekx; fil-holma bnina li sawwartilha hasset qalbha ddub u rtifset tal-Mulej ć-çaћda hanina u safa l-bniedem minnufih midrub fl-isbah setghet tal-qalb, $u$ bdiet ghalina hajja qalila taћt sultan maghdub.

We may not agree with Eliot that this is "the intolerable wrestle/With words and meanings", but words like fewgiet, xuxa, wtieqa, rżina, fiergha, safa, midrub, minnufih,

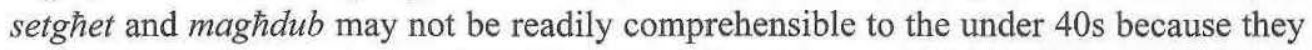
are less frequently-used nowadays. Moreover, the oblique meanings of ward, ghaddejja

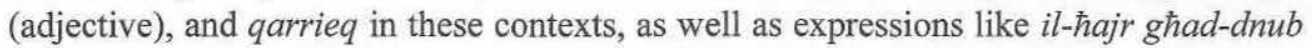

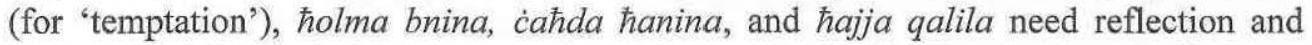
explanation. Of course, this is poetry, and many well-written poems are a challenge to the reader; an aspect of their beauty lies in their interpretation, but my aim here is simply to illustrate the distance between the two registers, not to make laudatory or derogatory comments for the one or the other. The fact that Dun Karm's style is consciously high-flown is shown by the following statistics.

\begin{tabular}{lccc}
\hline Categories of words & Dun Karm, Italian & Dun Karm, Maltese & Rużar Briffa \\
\hline Literary & 476 & 159 & 35 \\
Rare & 19 & 47 & 129 \\
Obsolete & 24 & 6 & \\
Self-coined (hapax) & 9 & 0 & \\
Technical, Specialized & 6 & 28 & 164 \\
Total of above & 534 & 240 & 1,890 \\
Headwords & 4,785 & 3,189 & $8.7 \%$ \\
\hline$\%$ of all headwords & $11.2 \%$ & $7.5 \%$ & \\
\hline
\end{tabular}

Table 4: Elegant and difficult words in classical poetry 
The high percentage of, above all, literary terms, but also of rare, obsolete, technical and specialized terms in Dun Karm's Italian poems $(11.2 \%)$ proves that his view of literary Italian was highly rhetorical, especially considering that they were written between 1889 and 1946. Recourse to Salvatore Battaglia's Grande Dizionario della Lingua Italiana, which lists abundant literary quotations under all the headwords, showed that, in fact, most of Dun Karm's "elegant" terms were taken from Dante, Petrarch, Ariosto, Tasso, and especially from Monti, Leopardi, Foscolo, Manzoni, Frugoni and Zanella. However, Dun Karm used considerably less literary terms in his Maltese poetry than in his Italian verse. Rather unexpectedly, one notes that Rużar Briffa's poems contain fewer literary and more numerous rare terms, and when combined their $8.7 \%$ surpasses Dun Karm's 7.5\% in his Maltese verse. At this point I wish to state that the definition of the various categories was carried out by the students, and that uniformity of judgment may not be impeccable. However, this being a first presentation of a work that is in progress, I am confident that their views on the lexicon of classical Maltese poetry are significant, also because they reflect the perception of the younger generation.

\section{Appendix}

\begin{tabular}{|c|c|c|c|c|}
\hline Word (inflectional forms) & Gr. Categ. & Tag & Etym. & Frequency \\
\hline Ruma (Ruma 41, Roma 1) & $n$. & TOP & It. & 42 \\
\hline $\begin{array}{l}\text { stenna (tistenna } 11 \text {, jistenna } 9 \text {, stennew } 9 \text {, ni- } \\
\text { stenna } 3 \text {, jistenniek } 2 \text {, stenniet } 2 \text {, jistennewh } 1 \text {, } \\
\text { jistennieni } 1 \text {, nistennik } 1 \text {, stennik } 1 \text {, tistennieh } 1 \text {, } \\
\text { tistennieni } 1 \text { ) }\end{array}$ & $v$. & $\mathrm{CO}$ & Ar. & 42 \\
\hline $\begin{array}{l}\text { wild (wild } 3 \text {, ulied } 7 \text {, uliedek } 6 \text {, uliedu } 5 \text {, uliedhom } \\
2 \text {, uliedkom } 1 \text {, uliedna } 1 \text {, wlied } 6 \text {, wliedek } 6 \text {, wliedi } \\
2 \text {, wliedha } 1 \text {, wliedna } 1 \text {, wliedu } 1 \text { ) }\end{array}$ & $n$. & $\mathrm{LU}$ & Ar. & 42 \\
\hline bhalma (bhalma 40, bhalm' 1) & prep. & GR & Ar. & 41 \\
\hline bosta & adj., n., adv. & $\mathrm{LU}$ & Ar. & 41 \\
\hline ghalhekk & $a d v$. & GR & Ar. & 41 \\
\hline poeta (poeta 38, poeti 3 ) & $n$. & $\mathrm{LU}$ & It. & 41 \\
\hline 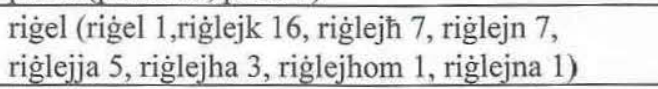 & $n$ & $\mathrm{LU}$ & Ar. & 41 \\
\hline bnin (bnin 19, bnina 21$)$ & adj. & $\mathrm{LU}$ & It. & 40 \\
\hline haġa (haġa 32 , hwejjeg 5 , ћwejǵu 2, hag'ohra 1) & $n$. & $\mathrm{CO}$ & Ar. & 40 \\
\hline htija (htija 39, htijiethom 1) & $n$. & $\mathrm{LU}$ & Ar. & 40 \\
\hline $\begin{array}{l}\text { hu (huna } 3 \text {, huh } 2 \text {, huk } 1 \text {, huta } 2 \text {, huti } 11 \text {, hutna } \\
8 \text {, hut } 4 \text {, hutek } 4 \text {, hutu } 4 \text {, hija } 1 \text { ) }\end{array}$ & $n$. & $\mathrm{CO}$ & Ar. & 40 \\
\hline
\end{tabular}

$\mathrm{TOP}=$ toponym $; \mathrm{CO}=$ commonly used $; \mathrm{LU}=$ low usage $; \mathrm{GR}=$ function word 


\section{References}

Ammon, Ulrich (1986): Explikation der Begriffe 'Standardvarietät' und 'Standard-sprache' auf normtheoretischer Grundlage, in: Holtus, Günter \& Radtke, Edgar (eds.), Sprachlicher Substandard. Tübingen: Niemeyer, 1-63.

Ammon, Ulrích (2004): Standard variety, in: Ammon, Ulrich; Dittmar, Norbert; Mattheier, Klaus J. \& Trudgill, Peter (eds.), Sociolinguistics: an international handbook of the science of language and society, Berlin/New York: De Gruyter, vol.1, 273-283.

Aquilina, Catherine (2008): Le parole italiane di Rużar Briffa. Unpublished B.A. Hons. dissertation, University of Malta.

Battaglia, Salvatore (1961-2002): Grande Dizionario della Lingua Italiana. Torino: UTET.

Berruto, Gaetano (1987): Sociolinguistica dell 'italiano contemporaneo. Roma: NIS.

Brincat Joseph M. (2000): Il-Malti. Elf Sena ta' Storja, Malta: PIN.

Brincat Joseph M. (2010): Maltese and other languages. A linguistic history of Malta, Malta: Midsea Books.

Brincat Joseph M. (2001): The language question and education: a political controversy on a linguistic topic, in: Sultana, Ronald (ed.), Yesterday's schools. Readings in Maltese educational history. Malta: PEG, 137-158.

Cassar Pullicino, Joseph (2001): Il-Kitba bil-Malti sal-1870. Malta: PIN.

De Brincat, Olivia (2009): Mappa lessicale della poetica italiana di Dun Karm. Unpublished B.A. Hons. dissertation, University of Malta.

De Mauro, Tullio (2000): Grande Dizionario Italiano dell'Uso. Torino: UTET.

Friggieri, Oliver (1976): Il-Kultura Taljana f'Dun Karm. Malta: KKM.

Friggieri, Oliver (1979): Storja tal-Letteratura Maltija. Vol. 1, Il-Poeżija mill-bidu sa Dun Karm. Malta: KKM.

Friggieri Oliver (ed.) (1980): Dun Karm. Il-Poeżiji Mig̈bura. Malta: KKM.

Friggieri, Oliver (ed.) (2007): Dun Karm. Le poesie italiane. Malta: Malta University Press.

Garvin, Paul \& Mathiot, Madeleine (1956): The urbanization of the Guarani language: a problem in language and culture, in: Wallace, Anthony F. C. (ed.), Men and cultures. Philadelphia: Univ. of Pennsylvania Press, 783-790.

Gramsci, Antonio (1975): Quaderni del carcere, edited by V. Gerratana, Turin: Einaudi.

Hull, Geoffrey (1993): The Malta language question. A case study in cultural imperialism. Malta: Said International.

Mifsud, Manuel \& Borg, Albert (1997): Fuq l-Ghatba tal-Malti: deskrizzjoni komunikattiva ta' l-ilsien Malti fuq il-mudell tat-Threshold Level 1990, Strasbourg: Council of Europe.

Romaine, Suzanne (1998): The Cambridge history of the English language, vol. IV, 1776-1997, in Hogg, Richard M. (ed.), The Cambridge history of the English language, 6 vols., Cambridge: Cambridge University Press, 1992-2001.

Sciberras, Christian (2009): Le parole italiane nella poesia di Dun Karm. Unpublished B.A. Hons. dissertation, University of Malta. 